\title{
DYNAMICS OF ASSOCIATION BETWEEN INDIAN STOCK MARKET AND INSTITUTIONAL INVESTORS IN THE LONG RUN AND SHORT RUN- A STUDY OF BSE SENSEX
}

\author{
DR. KAVITA
}

Assistant Professor, Delhi Institute of Advanced Studies, New Delhi

\begin{abstract}
Institutional investors have gained a remarkable role in the Indian stock market. In this Research paper, the trading behaviour of foreign institutional investors (FIIs) and domestic institutional investors (DIIs) has been investigated in relation to Indian stock market returns as proxied by BSE Sensex. The present study uses a wider description of DIIs by including not only mutual funds (MFs) but also other domestic financial institutions, banks and insurance companies who are active in the Indian stock market. The major objective of the study was to elucidate the existence of short-term and long-term causal relationship between the Foreign Institutional Investors Domestic Institutional Investors and the Indian stock market. The empirical techniques such as co-integration and Block Exogenity Wald Test as a part of research methodology have been employedfor the purpose of data analysis. Further the error correction term of Vector Error Correction Model (VECM) specifies the existence of long-run causal relationship. The Johansen's cointegration test results confirmed the presence of long term relationship between Institutional Investors and stock market indices. The studyrevealed that the investments by FIIs and Indian stock market as proxied by BSE are adjusting variables in the long run and no long term relationship was found in case of DIIs. However, the analysis of short term relationship indicated that the Indian stock Market is significantly influenced by the Foreign Institutional Investors and that the Domestic Institutional Investors are influenced by the Indian Stock Market.

KEYWORDS: Foreign Institutional Investors, Domestic Institutional Investors, Co-Integration, Time Series Wald Test Etc
\end{abstract}

Received: Jun 08, 2020; Accepted: Jun 28, 2020; Published: Sep 15, 2020; Paper Id.: IJMPERDJUN20201250

\section{INTRODUCTION}

The attention of the investors as well as policy makers has been perpetual towards the association of security returns with the institutional investment flow. In general, significant correlation is perceived to exist between the investment behaviour of institutional investors with the stock market returns. The vast literature provides numerous elucidations in that front. In the post liberalization period, with the entry as well as increased participation of the institutional investors, institutional investments observed a remarkable growth. Further, the withdrawal of funds by FIIs from the emerging markets owing to the emergence of sub prime mortgage crisis provided a significant importance to the investments by institutional investors.

The liberalization of rules and regulations for international investors contributed to the more active involvement of foreign institutional investors (FII) in the Indian stock market. Grave apprehensions in the host nations concerning the contrary effects of the withdrawal of investments by FIIs rose owing to the massive gauge of net portfolio transmissions to developing nations and hasty progression of international liquidity to other nations. The major causes of concerns included the jeopardy of financial volatility, augmented levels of consumer prices and 
asset prices and the problem of an amplification of the exchange rate. In the event of collapse of an economy due to external shock, these group of institutional investors were considered to withdraw their investments abruptly. In particular, this was perceived as a distress in the process of policy making because of the mounting burden on real exchange rates which came to prove portfolio inflows to be equivalent to portfolio outflows as far as their capacity to destabilise the investments is concerned. A substantial portion of the investment in aggregate investments by institutional investors is contributed by FII and internal institutional investors (DIIs). An imperative part of the Indian capital market is occupied by these two groups of institutional investors as evidenced by the prevailing literature.To clarify this connection, the literature offers three convex hypotheses. Firstly, the hypothesis of the dynamics of trade, which suggests a positive relationship between institutional investment and the backlog of stock market returns. Positive association between stock market returns and flows of institutional funds is postulated by the proposition of price pressure. This hypothesis also suggests a negative association between security market returns and lagging flows of funds. Improved trade owing to better accessibility of information related to trends in market is the one of the major propositions named as "information disclosure". The investments in FDI has witnessed a significant increase in the recent times. However, dissimilar trading behavior of DII and FII has been evidenced by the vast literature available in that direction.

The examination of the impact on stock returns has been conducted in the current study by undertaking analysis in the long as well as short term. Further, the association between both the institutional investors has also been scrutinised in this research paper.

\section{REVIEW OF LITERATURE}

A description of Review of Literature concerning investments by institutional investors is as follows:

Sharma (2011) studied the relationship between the economic growth of India and FDI inflows from 1996 to 2009. The prominent hypothesis regarding FII inflows impacting the Indian economic growth was rejected and the analysis confirmed that there is no significant impact of economic growth on the flows of FDI in India. Sultana and pardhasaradhi (2012) using 11 years data from 2000-2011 revealed that the trend of Indian stock market is determined by FDIs and FIIs in India. Sahu and Bandopadhyay (2013) studied the relationship between the Indian stock market and FIIs in India from the period 2000-2013. The analysis in the long run confirmed the existence of long term relationship between the variables under consideration. The results revealed that long-term causal relationship exists between the variables that has moved from the Indian stock market to FIIs, but contrasting results were found in the opposite direction. one-way causal relationship between the Indian stock market and short-term investments by FII was found from the Granger Causality Test. Bhasin and Khandelwal (2014) analysed the relationship between foreign institutional investment, foreign exchange reserves, and the exchange rate using ARDL technique. Exchange Rate was found to be a significantly affecting the movement of FIIs in India. Mehla and Goyal (2015) used monthly time series data on BSE and analysed the short-term as well as long-term causal relationship between FIIs and BSE. The researcher employed Granger causality test, the analysis of joint integration and variance decomposition for the analysis. Existence of long-term relationship between the dependent and the independent variables was confirmed from the results. A unidirectional causal relationship from the FIIs to the BSE Sensex was revealed from the analysis. Srinivasan and Kalaivani (2016) employed ARDL test to identify the determinants of foreign institutional investments (FIIs). The results indicated that devaluation of currency has an adverse impact on FII flows into India. The evidence of positive as well as negative feedback trading was found from the analysis in long as well as in short run. In the long run, the market returns of US equity was found to have a 
significant impact on FIIa whereas the impact was found to be insignificant in the long run. It was found that the risk factor with US equity market attracts the investments by FIIs. The level of inflation was found to have a negative impact in the long run, whereas the positive impact in the short run. The returns generated by domestic stock market, the inflation rate in the economy, and risk associated with US equity market were identified as the determinants of FII flows in India. Patel (2016) provided evidence of long term relationship amongst BSE, MXX, Hangseng, RTS, FTSE-100, Nikkei, BVS, and NASDAQ. Cella (2019) revealed that reduction in real investment undertaking too much investment is caused by upsurge in the ownership stake made by long-term institutional investors. Further, the study revealed that short-term investors do not have any impact on investment. Sakaki and Jori (2019) examined the association between level of innovation by investee firms and institutional ownership. Stability in the equity ownership of institutional investors was found to have a direct relationship with another variable under consideration. The study found a positive association between mutual funds dynamically handling their funds diverse from benchmark index and firm innovation.

\section{OBJECTIVES OF THE STUDY}

- To find the long-term relationship between the net flows of the institutions and return of the Indian stock market.

- To find the short-term relationship between the net flows of the institutions and return of the Indian stock market.

\section{RESEARCH METHODOLOGY}

\section{Data and Methodology}

The data used for the analysis included monthly time series data on the close of the BSE Sensex index and ratio of gross purchases to sales of foreign as well as domestic institutional investors. The data set included the period from April 2008 to March 2019. The original data for the analysis consists of closing prices. While calculating returns and their first differencing, the statistical software itself undertakes the analysis with the reduced number of observations. The analysis was carried out by using 132 monthly observations which were subsequently reduced to 127 data points by the software in the process of computations.. The final data related to the BSE Sensex index was obtained from the Yahoo Finance website, and the data related to institutional investors were obtained from the official money control website. Eviews-9 were used to organize data and conduct econometric analysis.Institutional investments are taken as ratios of gross purchases to sales of both categories of institutional investors, that is, foreign and domestic. This has been done to avoid the problem of Unit root or problem of non stationarity involved in time series data. In addition, empirical tools, such as joint integration and the Block Exogenity Wald test, are used as part of the research methodology to achieve research objectives.

\section{Hypothesis of the Study}

H0: There is no significant relation between institutional investors and Indian stock market return.

Ha: There is a significant relation between institutional investors and Indian stock market return.

\section{Analysis and Interpretation}

Monthly data analysis was carried out using various econometric tools, such as the ADF root module test, Johansen integration test, vector error correction model and Block Exogienity Wald test. For data analysis, Microsoft Excel and Eviews 9 were used. Before analyzing the properties of the root element of the series in question, it is better to take the log variable. Therefore, BSE Sensex, FII and DII were taken for further analysis.

\section{Unit Root Test}


The stationarity property of time series data is necessary to be investigated to examine the applicability of any specific test under consideration. A series is known as stationary if it has a constant mean value, constant auto-covariances and constant dispersion for each given lag. Among several unit root tests, the ADF root test was used in the present study so as to investigate the stationary properties of time-series data.Table 1 shows the results of ADF Unit Root Test.

Table 1: Results of ADF Unit Root Test

\begin{tabular}{|l|c|c|c|}
\hline \multicolumn{1}{|c|}{ Variable } & ADF test Statistics & $\begin{array}{c}\text { Probability } \\
\text { values at } \\
\text { level ('p' } \\
\text { values) }\end{array}$ & $\begin{array}{c}\text { Probability values } \\
\text { after first } \\
\text { differencing }\end{array}$ \\
\hline BSE Sensex & 0.491970 & 0.8880 & 0.000 \\
\hline $\begin{array}{l}\text { Foreign } \\
\text { Institutional } \\
\text { Investors }\end{array}$ & 2.584640 & 0.0990 & 0.000 \\
\hline $\begin{array}{l}\text { Domestic } \\
\text { Institutional } \\
\text { Investors }\end{array}$ & 0.157963 & 0.9784 & 0.000 \\
\hline Critical Values & & & \\
\hline 1 Percent & -3.481217 & & \\
\hline 5 Percent & -2.883753 & & \\
\hline 10 Percent & -2.578694 & & \\
\hline
\end{tabular}

Source: Author's own compilation

The result of Augmented Dickey Fuller test, as shown in Table 1, indicates that the series is integrated in the first order. This indicates that the integration of both series is of the order of I (1). The results reveal that at before differencing, the values of "p" are 0.8880, 0.0990, and 0.9784 for BSE Sensex, foreign institutional investors, and domestic institutional investors, respectively. The null hypothesis of the test is that the data is non stationary. Since, the 'p' values are greater than 0.05 , the null hypothesis of the test will be accepted. After first differencing, the 'p' values are less than 0.05 in case of all the variables. This clearly indicates that the data is integrated of order 1. This fulfills primary condition for applicability of Joint Johansen Integration test. Data has become stationary after the first difference, thereby fulfilling the first condition for applying the cointegration test. After the stationary properties of the series are determined, the next step is to check whether the series in question are integrated or not. Integration of same order of data is a prerequisite for applying the Johansen cointegration test and deploying an error correction model to study the long-term relationship between variables.

\section{Co-Integration Test}

Joint integration amongst the variables is required to be tested if the variables under consideration are integrated of order 1 or I (1). Before proceeding to apply the technique for analysis, natural log of both the dependent and the independent variable was calculated. The number of equations involving co-integration is estimated empirically under this technique. The results of eigenvalue test statistics and trace test statistics are used to decide the number of cointegrating vectors.

"Let wt be a k X 1 vector of variables, then the components of wt are integrated of order(d,b) if:

(1) All components of wt are I(d)

(2) There is at least one vector of coefficients $\alpha$ such that $\alpha$ wt I (d-b)

Wt vector is a vector of simple variable or random variable 
The null hypotheses of both of their test statistics are tested to analyze the presence of cointegration between the variables. In the case of statistics on a trace test, the null hypothesis is that the number of cointegrating vectors is less than or equal to $r$, in which $r$ is $0,1,2,3$, etc. An alternative hypothesis for test is that $r=n$. the test results of Max-eigenvalue is referred if the outcomes of both are contradictory. If the test results indicate the presence of atleast 1 equation reflecting cointegration, then a causal relationship amongst the variables can be established by using the vector error correction model (VECM) technique. The existence of one cointegration equation is revealed from the test results. A long-term relationship between between the variables under consideration.

In practice, many financial variables contain a unit root and therefore are I (1) (Brooks, 2008)". There may be time series which contain a unit root but may not be I(1). Against this background, a set of variables is marked as cointegrated if their linear combination is stationary. It is a general observation that due to existence of some stimuluses on the series(for instance, market forces), data series may exhibit themselves to be unified by some associations for a extensive period of time, even when the data under consideration is non stationary. Due to a likelihood of variation of cointegration variables in the short tenure, their behavior is checked so as to examine the presence of long term relationship between them.

Cointegration analysis is used to determine the extent to which the two series move together towards a long-term equilibrium relationship. Johansen and Jozelius (1990) used the cointegration approach for this purpose. The null hypothesis of the equation is that there exists ' $r$ ' co-integrating relationships between the variables. The alternate hypothesis lays that there exists ' $r+1$ ' cointegrating relationships. This indicates that in the latter case, the number of relationships exceed by 1 . To decide about the number of lags to be included, lag exclusion test was used and the entire analysis was undertaken by considering the estimated number of lag lengths.

Table 2: Results of Johansen Co integration Test

\begin{tabular}{|l|c|c|c|c|}
\hline \multicolumn{5}{|c|}{ Unrestricted Co integration Rank Test (Trace) } \\
\hline Hypothesized & \multicolumn{1}{c|}{ Trace } & $\mathbf{0 . 0 5}$ & \\
\hline No. of CE(s) & Eigenvalue & Statistic & Critical Value & Prob.** \\
\hline None * & 0.217452 & 37.56499 & 35.19275 & 0.0272 \\
\hline At most 1 & 0.033984 & 6.424634 & 20.26184 & 0.9301 \\
\hline At most 2 & 0.015885 & 2.033643 & 9.164546 & 0.7710 \\
\hline Trace test indicates 1 co integratingeqn(s) at the 0.05 level \\
\hline$*$ denotes rejection of the hypothesis at the 0.05 level \\
\hline$* *$ MacKinnon-Haug-Michelis (1999) p-values \\
\hline \multicolumn{5}{|c|}{ Unrestricted Co integration Rank Test (Maximum Eigen value) } \\
\hline Hypothesized & Max-Eigen & 0.05 & Critical Value \\
\hline No. of CE(s) & Eigenvalue & Statistic & Prob.** \\
\hline None * & 0.217452 & 31.14036 & 22.29962 & 0.0023 \\
\hline At most 1 & 0.033984 & 4.390991 & 15.89210 & 0.9346 \\
\hline At most 2 & 0.015885 & 2.033643 & 9.164546 & 0.7710 \\
\hline Max-eigenvalue test indicates 1 cointegratingeqn(s) at the 0.05 level \\
\hline$*$ denotes rejection of the hypothesis at the 0.05 level \\
\hline$* *$ MacKinnon-Haug-Michelis (1999) p-values \\
\hline
\end{tabular}

Source: Author's own compilation

The results of the joint integration of Johansen and Juzelius between BSE Sensex, FII and DII were presented in Table 2 and Table 3. For the specification of the cointegration test, the results of the trace test and the maximum eigenvalue are presented in the tables. Unrestricted Cointegration Rank Test (Max-eigen value method) has been used. Intercept (no trend) in Cointegration equation and no intercept in VAR has been used for the analysis. There are two types 
of Johansen test, either with trace or with eigenvalue. The null hypothesis for the trace test is that the number of cointegration vectors is $r=r^{*}<k$, vs. the alternative that $r=k$. Testing proceeds sequentially for $r^{*}=1,2$, etc. and the first non-rejection of the null is taken as an estimate of $r$. The null hypothesis for the "maximum eigenvalue" test is as for the trace test but the alternative is $r=r^{*}+1$ and, again, testing proceeds sequentially for $\mathrm{r}^{*}=1,2$, etc., with the first nonrejection used as an estimator for $r$. Four lags were selected on the basis of lag exclusion test. The results of analysis revealed that there are no cointegrating vectors both in trace statistics and in maximum eigenvalues, as evidenced by a value of "p" 0.0272 and 0.0023 respectively. This indicates the rejection of the null hypothesis and hence leads to a conclusion that the variables under examination are related to each other in the long run. The null hypothesis of not more than 1 cointegrating equation will be accepted in the case of a trace, as well as the maximum eigenvalue at a significance level of $5 \%$, as indicated by p values equal to 0.9301 and 0.9346 , respectively. So, the test indicates the presence of one cointegrating equation at the level of 0.05 . In other words, confirmation of the existence of joint integration excludes not causality among the variables, and also means the possibility of the presence of at least unidirectional causality from one variable to another.

Therefore, error correction model can be used so as to identify the variable which affects another variable in the long run. The results of the vector error correction model are shown in table 3. In the case of the FII investments, the statistic value " $\mathrm{t}$ " is 7.5193, which is more than 2. This means that the basic condition for applying ECM is fulfilled.

Table 3: Results of Error Correction Model
\begin{tabular}{|c|c|}
\hline Co integratingEq: & CointEq1 \\
\hline SENSEX(-1) & 1.000000 \\
\hline & \\
\hline LOGF(-1) & -21893.63 \\
\hline & $(2911.66)$ \\
\hline & {$[-7.51930]$} \\
\hline & -863.7677 \\
\hline LOGD(-1) & $(2362.83)$ \\
\hline & {$[-0.36557]$} \\
\hline & 230828.4 \\
\hline & $(18226.8)$ \\
\hline C & {$[12.6642]$} \\
\hline
\end{tabular}

Source: Author's own compilation

Table 3 shows the results of Error Correction Model can be used so as to identify the variable which affects another variable in the long run. The results of the vector error correction model are shown in table 3. In the case of the FII investments, the statistic value " $\mathrm{t}$ " is 7.5193, which is more than 2. This means that the basic condition for applying ECM is fulfilled.

\section{Table 4: Results of Vector Error Correction Model}

As the stock market indices are integrated of the same order I (1), the Johansen and Juselius tests are run for estimating the cointegration or the long-run relationship among them (Johansen and Juselius, 1990).

\begin{tabular}{|c|c|c|c|}
\hline Error Correction: & D(Sensex) & D(Logf) & D(Logd) \\
\hline CointEq1 & 0.109732 & $3.43 \mathrm{E}-05$ & $1.07 \mathrm{E}-05$ \\
\hline & $(0.03555)$ & $(6.6 \mathrm{E}-06)$ & $(5.8 \mathrm{E}-06)$ \\
\hline & {$[3.08674]$} & {$[5.22815]$} & {$[1.84869]$} \\
\hline
\end{tabular}




\begin{tabular}{|c|c|c|c|}
\hline \multirow{3}{*}{$\mathrm{D}(\operatorname{SENSEX}(-1))$} & -0.209554 & $2.67 \mathrm{E}-05$ & $6.79 \mathrm{E}-05$ \\
\hline & $(0.11000)$ & $(2.0 \mathrm{E}-05)$ & $(1.8 \mathrm{E}-05)$ \\
\hline & {$[-1.90512]$} & [ 1.31627] & [3.78662] \\
\hline \multirow{3}{*}{$\mathrm{D}(\operatorname{SENSEX}(-2))$} & -0.170521 & $1.46 \mathrm{E}-05$ & $5.82 \mathrm{E}-05$ \\
\hline & $(0.11031)$ & $(2.0 \mathrm{E}-05)$ & (1.8E-05) \\
\hline & {$[-1.54583]$} & [0.71869] & [3.23533] \\
\hline \multirow[t]{3}{*}{$\mathrm{D}(\operatorname{SENSEX}(-3))$} & 0.195442 & $8.61 \mathrm{E}-06$ & $1.47 \mathrm{E}-05$ \\
\hline & $(0.11021)$ & $(2.0 \mathrm{E}-05)$ & $(1.8 \mathrm{E}-05)$ \\
\hline & [1.77333] & [0.42328] & [0.81967] \\
\hline \multirow[t]{3}{*}{$\mathrm{D}(\operatorname{SENSEX}(-4))$} & 0.099846 & $-8.10 \mathrm{E}-06$ & $-1.96 \mathrm{E}-05$ \\
\hline & $(0.11086)$ & $(2.0 \mathrm{E}-05)$ & $(1.8 \mathrm{E}-05)$ \\
\hline & [0.90066] & {$[-0.39612]$} & {$[-1.08322]$} \\
\hline \multirow[t]{3}{*}{$\mathrm{D}(\mathrm{LOGF}(-1))$} & 2867.566 & 0.041661 & 0.014860 \\
\hline & (863.079) & $(0.15924)$ & $(0.14067)$ \\
\hline & [3.32248] & [0.26162] & [0.10564] \\
\hline \multirow{3}{*}{$\mathrm{D}(\mathrm{LOGF}(-2))$} & 2848.888 & 0.033093 & -0.069553 \\
\hline & (816.426) & $(0.15063)$ & $(0.13306)$ \\
\hline & [ 3.48946] & [ 0.21969$]$ & {$[-0.52271]$} \\
\hline \multirow[t]{3}{*}{$\mathrm{D}(\mathrm{LOGF}(-3))$} & 783.9018 & 0.048434 & 0.063152 \\
\hline & $(761.971)$ & $(0.14059)$ & $(0.12419)$ \\
\hline & [ 1.02878$]$ & [0.34452] & [0.50852] \\
\hline \multirow[t]{3}{*}{$\mathrm{D}(\mathrm{LOGF}(-4))$} & -114.9527 & 0.118128 & 0.182337 \\
\hline & (620.787) & $(0.11454)$ & $(0.10118)$ \\
\hline & {$[-0.18517]$} & [ 1.03135$]$ & [ 1.80215] \\
\hline \multirow{3}{*}{$\overline{\mathrm{D}(\operatorname{LOGD}(-1))}$} & -855.5367 & -0.097312 & -0.482674 \\
\hline & (719.046) & $(0.13267)$ & $(0.11719)$ \\
\hline & [-1.18982] & {$[-0.73351]$} & [-4.11866] \\
\hline \multirow[t]{3}{*}{$\mathrm{D}(\mathrm{LOGD}(-2))$} & -338.5853 & 0.176748 & -0.134780 \\
\hline & (790.734) & $(0.14589)$ & $(0.12888)$ \\
\hline & [-0.42819] & [ 1.21149] & {$[-1.04581]$} \\
\hline \multirow[t]{3}{*}{$\mathrm{D}($ LOGD $(-3))$} & 847.3085 & 0.149679 & -0.117533 \\
\hline & $(745.130)$ & $(0.13748)$ & $(0.12144)$ \\
\hline & [ 1.13713] & [ 1.08874] & {$[-0.96780]$} \\
\hline \multirow{4}{*}{$\mathrm{D}(\operatorname{LOGD}(-4))$} & & & \\
\hline & 1600.109 & 0.134594 & -0.196263 \\
\hline & $(580.063)$ & $(0.10702)$ & $(0.09454)$ \\
\hline & [2.75851] & [1.25761] & {$[-2.07598]$} \\
\hline R-squared & 0.199195 & 0.428226 & 0.447988 \\
\hline Adj. R-squared & 0.114900 & 0.368039 & 0.389881 \\
\hline Sum sq. resids & $1.32 \mathrm{E}+08$ & 4.477205 & 3.493654 \\
\hline S.E. equation & 1074.104 & 0.198176 & 0.175060 \\
\hline F-statistic & 2.363067 & 7.114959 & 7.709756 \\
\hline Log likelihood & -1059.712 & 32.21426 & 47.96548 \\
\hline Akaike AIC & 16.89310 & -0.302587 & -0.550637 \\
\hline Schwarz SC & 17.18423 & -0.011449 & -0.259500 \\
\hline
\end{tabular}




\begin{tabular}{|c|c|c|c|}
\hline Mean dependent & 138.9770 & 0.006438 & 0.008632 \\
\hline S.D. dependent & 1141.695 & 0.249291 & 0.224120 \\
\hline \multicolumn{2}{|c|}{ Determinant resid covariance (dof adj.) } & 772.1573 & \\
\hline \multicolumn{2}{|c|}{ Determinant resid covariance } & 558.4820 & \\
\hline \multicolumn{2}{|l|}{ Log likelihood } & -942.2672 & \\
\hline \multicolumn{2}{|c|}{ Akaike information criterion } & 15.51602 & \\
\hline \multicolumn{2}{|l|}{ Schwarz criterion } & 16.47901 & \\
\hline
\end{tabular}

Source: Author's own compilation

The model type (VAR or VECM) selection decision is based on the result of the Johansen and JuseliusCointegration Tests. Table 4 shows the results of Vector Error Correction Model. Standard errors are shown in normal brackets ( ) \& t-statistics are given in square brackets [ ]. As both the Trace and Maximum Eigenvalue tests indicate the existence of Cointegration at 5\% level, the VECM model is used for further analysis. ECM results show that the statistic value " $\mathrm{t}$ " is greater than 2 in the case of FII and Sensex. Thus, FIIs and Sensex are the adjusting variables in the VECM analysis. The results also indicate that Sensex returns at lag 1 and lag 2 influence the investments by Domestic Institutional Investors in the Long Run. The significant ' $t$ ' statistics value of 3.32248 and 3.348946 revealed that stock market returns act as adjusting variables in response to the investments by Foreign Institutional Investors at lag 1 and lag 2. Therefore, theresults of Error Correction Model and shows that the statistic value " $\mathrm{t}$ " is greater than 2 in the case of FII and Sensex.Thus, FIIs and Sensex are the corrective variables in the VECM analysis. In case of DIIs, the value of ' $t$ ' is less than 2, it indicates that DIIs do not act as corrective variables in the long run.

\section{Findings from Short-Run Analysis}

Investments by FIIs, DIIs and BSE Sensex returns were tested to examine the existence of short term relationship by employing Block Exogenity Test. Afterwards, the cumulative effect of all lags has been examined. The null hypothesis for the test is that a variable can be excluded. The alternate hypothesis of the test is that the variable should not excluded. It lays that the variable will be included and will be considered to have an impact in the short run. It indicates that this variable is leading other variable with respect to another variable. The results of Wald test has been shown in the Table-5.

Table 5: VAR Granger Causality/Block Exogeneity Wald Test for BSE Sensex

Returns and Investments by Institutional Investors

\begin{tabular}{|c|c|c|c|}
\hline \multicolumn{3}{|c|}{ Dependent Variable: D(SENSEX) } & \multirow[b]{2}{*}{ Prob. } \\
\hline Excluded & Chi-sq & df & \\
\hline $\mathrm{D}(\mathrm{LOGF})$ & 17.73999 & 4 & 0.0014 \\
\hline $\mathrm{D}(\mathrm{LOGD})$ & 10.17620 & 4 & 0.0376 \\
\hline All & 26.34689 & 8 & 0.0009 \\
\hline \multicolumn{4}{|c|}{ Dependent Variable: D(LOGF) } \\
\hline Excluded & Chi-sq & df & Prob. \\
\hline D(SENSEX) & 2.186107 & 4 & 0.7016 \\
\hline $\mathrm{D}(\mathrm{LOGD})$ & 4.833533 & 4 & 0.3048 \\
\hline All & 7.647094 & 8 & 0.4687 \\
\hline \multicolumn{4}{|c|}{ Dependent Variable: D(LOGD) } \\
\hline Excluded & Chi-sq & df & Prob. \\
\hline $\mathrm{D}(\mathrm{SENSEX})$ & 22.19826 & 4 & 0.0002 \\
\hline $\mathrm{D}$ (LOGF) & 5.018309 & 4 & 0.2854 \\
\hline All & 46.09746 & 8 & 0.0000 \\
\hline
\end{tabular}

Source: Author's own compilation

Table 5 Shows the results of Block Exogeneity Wald Test. In the case of BSE Sensex as a dependent variable and FII and DII as an independent variable, the value of "p" is 0.0014 for FII and 0.0376 for DII. This indicates that FII and DII 
play an important role in influencing BSE Sensex. In the case of FII as a dependent variable and Sensex and DII as an independent variable, the value of "p" is 0.7016 in the case of Sensex and 0.3048 in the case of DII. This indicates that both DII and Sensex do not play a significant role in the granulators that cause FII, and that there may be some other determinants that affect the flow of FII in India.In the case of DII as a dependent variable and FII and Sensex as an independent variable, the value of "p" is 0.0002 and 0.2854 respectively. This indicates that the stock market plays an important role and act as leading variables in influencing the investments by DIIs and that FIIs do not lead the investments by DIIs.

\section{CONCLUSIONS}

A substantial investments in the Indian stock market is contributed by Institutional investors. An empirical investigation of existence of relationship between stock market and these category of investors has been undertaken using econometric methods. The existence of long-run causal relationship was found to be existing as revealed from the analysis using Vector Error Correction Model (VECM). Further, the presence of long term relationship between Institutional Investors and stock market indices was confirmed from the results of Johansen's cointegration test. The studyrevealed that the investments by FIIs and Indian stock market as proxied by BSE are adjusting variables in the long run and no long term relationship was found in case of DIIs. However, the analysis of Block Exogeneity Wald Testindicated that, in the short run, the Indian stock Market is significantly influenced by the Foreign Institutional Investors and that the Domestic Institutional Investors are influenced by the Indian Stock Market.The present research paper is unique in the sense that it focuses on both the categories of institutional investors and undertakes the analysis using Vector Error Correction Model, Johansen's cointegration and Block Exogenity Wald Test so as to analyse the association both in the short as well as in the long run. This explanation was earlier missing in the research paper which has now been included. It also showed that DIIs follow the trends of stock market while undertaking investment decisions.

\section{Policy Implications}

This research is relevant for the policy makers in responding to increasing interaction between institutional investors and Indian stock market return. The value of this research for the government agencies is that they can focus on managing short term, non-debt creating flows to Indian stock market in a pragmatic and improved manner. Appropriate action by the policy makers/emerging economies will, in turn, keep FIIs in check and encourage the fund flow by Domestic Institutional Investors.

\section{REFERENCES}

1. Aktar, I. (2009). Is there any comovement between stock markets of Turkey, Russia and Hungary. International Research Journal of Finance and Economics, 26 (1) 192 - 200.

2. Babu, M., \& Srinivasan, S. (2014). Testing the co-integration in Indian commodity markets : A study with reference to Multi Commodity Exchange India Ltd. Indian Journal of Finance, 8 (3), 35 - 43. DOI: 10.17010/ijf/2014/v8i3/71961.

3. Bhar, R., \&Hamori, S. (2008). A new approach to analyzingcomovement in European equity markets. Studies in Economics and Finance, 25 (1), 4 - 20. doi : https://doi.org/10.1108/10867370810857531

4. Bhasin, N. and Khandelwal, V. (2014), "Relationship between Foreign Institutional Investment, Exchange Rate and Foreign Exchange Reserves: The Case of India using ARDL Bounds Testing Approach”, International Journal of Financial Management, Vol. 4, No.2, pp. 33-39.

5. Bhattacharjee, S., \& Swaminathan, A. M. (2016). Stock market integration of India with rest of the world: An empirical study. Indian Journal of Finance, 10 (5), 22 - 32. DOI: 10.17010/ijf/2016/v10i5/92934 
6. Chakrabarty, A., \& Ghosh, B. K. (2011). Long run financial market cointegration and its effect on international portfolio diversification. Indian Journal of Finance, 5 (4), 27-37.

7. Chandra, P. (2017). Investment analysis and portfolio management. India : Tata McGraw Hill Education Private Limited.

8. Chen, S. W., \& Shen, C. H. (2009). Can the nonlinear present value model explain the movement of stock prices. International Research Journal of Finance and Economics, 23,155 - 170.

9. Cheung, Y. L., \&Mak, S. C. (1992). The international transmission of stock market fluctuation between the developed markets and the AsianPacific markets. Applied Financial Economics, 2(1), 43 - 47. DOI : http://dx.doi.org/10.1080/758527545

10. Dhingra, V.S., Gandhi, S. and Bulsara, H.P. (2016), "Foreign institutional Investments in India: An Empirical Analysis of Dynamic Interactions with stock market return and volatility”, IIMB Management Review, Vol.28, pp. 212-224.

11. Dunis, C., Sermpinis, G., \&Karampelia, M. F. (2013). Stock market linkages among new EMU members and the Euro area: Implications for financial integration and portfolio diversification. Studies in Economics and Finance, 30 (4), 370 - 388. doi : https://doi.org/10.1108/SEF-042012-0048

12. Garg, A. and Bodla, B.S. (2011), "Impact of the Foreign Institutional Investments on Stock Market: Evidence from India", Indian Economic Review, Vol. 46, No. 2, pp. 303-322.

13. Granger, C. W. (1969). Investigating causal relations by econometric models and cross-spectral methods. Econometrica: Journal of the Econometric Society, 37 (3), 424 - 438.

14. Hilliard, J. E. (1979). The relationship between equity indices on world exchanges. The Journal of Finance, 34 (1), 103 - 114.

15. Hoque, H. A. A. B. (2007). Co-movement of Bangladesh stock market with other markets: Cointegration and error correction approach. Managerial Finance, 33(10), 810 - 820. DOI : https://doi.org/10.1108/03074350710779250

16. Hutcheson, G. D., \&Sofroniou, N. (1999). The multivariate social scientist: Introductory statistics using generalized linear models. London : Sage.

17. Jang, H., \& Sul, W. (2002). The Asian financial crisis and the co-movement of Asian stock markets. Journal of Asian Economics, 13 (1), 94 104.

18. Johnson, R., \&Soenen, L. (2009). European economic integration and stock market co-movement with Germany. Multinational Business Review, 17 (3), 205 - 228. DOI : https://doi.org/10.1108/1525383X200900024

19. Karim, B. A., \& Ning, H. X. (2013). Driving forces of the ASEAN-5 stock markets integration. Asia-Pacific Journal of Business Administration, 5 (3), 186 - 191. DOI : https://doi.org/10.1108/APJBA-07-2012-0053

20. Leech, N. L., Barrett, K. C., \& Morgan, G. A. (2005). SPSS for intermediate statistics: Use and interpretation. New Jersey: Psychology Press.

21. MacKinnon, J. G., Haug, A. A., \&Michelis, L. (1999). Numerical distribution functions of likelihood ratio tests for cointegration. Journal of Applied Econometrics, 14 (5), 563 - 577.

22. Majumdar, S.B. and Nag, R.N. (2013), "Foreign Institutional Investment, Stock Market and Volatility: Recent Evidence from India", Indian Journal of Finance, Vol.7, pp. 23-31.

23. Majid, M. S. A., Meera, A. K. M., Omar, M. A., \& Aziz, H. A. (2009). Dynamic linkages among ASEAN-5 emerging stock markets. International Journal of Emerging Markets, 4(2), 160-184. doi : https://doi.org/10.1108/17468800910945783

24. Mehla, S. and Goyal, S. (2013), "Impact of Foreign Institutional Investment on Indian Stock Market: A Cause and Effect Relationship", AsiaPacific Journal of Management Research and Innovation, Vol. 9, No. 3, pp. 329-335.

25. Mitra, A., \& Bhattacharjee, K. (2015). Financial interdependence of international stock markets : A literature review. Indian Journal of Finance, 9 (5), 20 - 33. DOI: 10.17010/ijf/2015/v9i5/71447

26. Patel, R. (2017), "Comovement and Integration among stock markets- A study of fourteen countries", Indian Journal of Finance, Volume 11, Issue 9, September 2017. 
27. Qadan, M., \&Yagil, J. (2015). Are international economic and financial co-movements characterized by asymmetric co-integration? Review of Accounting and Finance, 14(4), 398 - 412. DOI : https://doi.org/10.1108/RAF-02-2015-0026

28. Seth, N., \& Sharma, A. K. (2015). International stock market efficiency and integration: evidences from Asian and U.S. markets. Journal of Advances in Management Research, 12(2), 88 - 106. DOI : https://doi.org/10.1108/JAMR-07-2011-0010

29. Shahzad, S. J. H., Kanwal, M., Ahmed, T., \& Rehman, M. U. (2016). Relationship between developed, European and South Asian stock markets: A multivariate analysis. South Asian Journal of Global Business Research, 5 (3), 385 - 402. doi.org/10.1108/SAJGBR-01-2015-0002

30. Sharma, J. (2019), “Market Integration and Efficiency of Indian Stock Markets: A

31. Study of NSE", Available online at www.nseindia.com, Accessed on 29.05.2019.

32. Srinivasan, P., \&Kalaivani, M. (2010), "Foreign Institutional Investment and Stock Market Returns in India: Before and during global financial crisis", The IUP Journal of Behavioral Finance, Vol. 7, No. 1-2, pp. 59-75

33. Srinivasan P, Kalaivani M (2013), "Determinants of Foreign Institutional Investment in India: An Empirical Analysis”, Journal of Academic Research in Economics, Vol. 5, No. 3, pp.361-375.

34. Vohra, P. S. (2016). A study of co-movement among indices of Bombay Stock Exchange. Indian Journal of Finance, 10 (9), 11 - 29. DOI: 10.17010/ijf/2016/v10i9/101476

35. Wong, W. K., Agarwal, A., \& Du, J. (2004). Financial integration for India stock market: A fractional co-integration approach. Finance India, 18 (4), $1581-1609$.

\section{WEBSITES}

- http://www.bseindia.com/indices/IndexArchiveData.aspx

- http://www.moneycontrol.com/india/stockmarket/foreigninstitutionalinvestors/12/57/activity/MF/201004

- http://www.moneycontrol.com/ 

